\title{
A comparison of health-related quality of life among knee os- teoarthritis patients in two cities in Pakistan
}

\author{
Saeed Taj Din ${ }^{a^{*}}$, Hafiza Tayaba ${ }^{\mathrm{b}}$ \\ ${ }^{a}$ Assistant Professor of Orthopaedic Surgery, Azra Naheed Medical College, Lahore, Pakistan. \\ ${ }^{b}$ Physical Therapist, City hospital, Sialkot, Pakistan.
}

\begin{abstract}
Background: Osteoarthritis (OA) is a major cause of disability that impacts health and activities of daily living, mostly affecting the hip and knee joints. Patients commonly present with symptoms of stiffness and pain in the affected joints. As an age-related chronic disease of the joint cartilage, degenerative osteoarthritis is very common among elderly people worldwide.

Objective: To compare health-related quality of life among patients with knee osteoarthritis in two cities in Pakistan: Lahore and Sialkot.

Methods: In a cross-sectional comparative study, data were collected from patients ( $\mathrm{N}=158 ; 105$ female; 53 male) aged 40 years or older, based on inclusion criteria adopted from government and private hospitals and clinics in Lahore and Sialkot and using the SF12 questionnaire and convenience sampling. The sample was evenly divided between the two cities.

Results: Earlier studies have shown that lifestyle in major urban centers is more sedentary than in smaller cities. However, independent sample t-testing $(\mathrm{p}=0.57)$ revealed no significant difference in health-related quality of life between knee osteoarthritis patients in Lahore (a major urban center) and Sialkot (which is less urbanized). Conclusion: Health-related quality of life in knee OA patients in Lahore and Sialkot was effectively the same in terms of disability level and awareness.

Keywords: Osteoarthritis; activities of daily living; health-related quality of life
\end{abstract}

\section{INTRODUCTION}

Osteoarthritis (OA) is a chronic disease of the joint, in which bone and joint cartilage break down ${ }^{[1]}$. OA is the most common type of joint disease among elderly people worldwide in both developing and developed countries, with significant consequences for health and activities of daily living (ADL). Symptoms include stiffness, pain, debilitating and significant disability, and poor performance of physical and social tasks, impacting the individual's general health and causing difficulty in walking, squatting, and stair climbing. Older people who have been diagnosed with $\mathrm{OA}$ are also likely to be long-term users of medication and physical therapy ${ }^{[2,3]}$. There is evidence that the prevalence of OA continues to increase, affecting $10-20 \%$ of the elder population,

*Corresponding author: Saeed Taj din

Mailing address: Orthopaedic Surgery, Azra naheed medical college, Lahore, Pakistan.54000.

E-mail: drsaeedpk2003@yahoo.com

Received: 23 August 2019 Accepted: 29 November 2019 and it is likely to be the seventh most common disease by 2020 . The condition is more prevalent among women and elderly people than among men aged 45-65 ${ }^{[4]}$. Other evidence suggests that knee OA is more common than hip OA, notably among people of Asian origin; that pain increases by $23 \%$ after the age of 55 and by $39 \%$ after the age of 65 years ${ }^{[2]}$. In general, OA is thought to affect $14.7 \%$ of women and $10.5 \%$ of men ${ }^{[5]}$; OA of the knee affects $11 \%$ of women and $7 \%$ of men, and a $40 \%$ increase in incidence is forecast by $2025^{[6-8]}$. Among younger people aged 25-35, the main causes of knee OA are trauma, poor nutrition, prolonged knee bending, and ligamentous injury while obesity is the major cause of bilateral knee $\mathrm{OA}^{[9-11]}$.

Health-related quality of life is improved by better assessment and early diagnosis of $\mathrm{OA}^{[12]}$. Physical activity improves quality of life among knee OA patients, and regular exercise reduces the risk of diseases such as diabetes, osteoporosis, hypertension, and obesity. As a key element in managing knee $\mathrm{OA}$, maintaining regular exercise is challenging for these patients. Early diagnosis helps to control the disease more effectively, and patient education and behavior intervention is of great help in 
slowing its progression ${ }^{[13-15]}$.

The objective of the present study was to compare health-related quality of life among knee OA patients in Lahore and Sialkot. Degenerative joint disease commonly affects weight-bearing joints, especially the knee joints, and the patient's quality of life is further undermined by a lack of understanding of the disease and the need for lifestyle modification. The study rationale is that these patients' quality of life can be enhanced by educating the general population about knee OA. The null hypothesis was that there is no difference in quality oflife among patients of knee OA; the alternative hypothesis was that there is a difference in the quality of life of knee OA patients in Sialkot and Lahore.

\section{Literature Review}

One cross-sectional study ${ }^{[12]}$ assessed quality of life among knee OA patients and the elder population using the WOMAC and SF-36 questionnaires. Based on a sample of 244 patients ( 145 female, 99 male) aged more than 50 years, they concluded that health-related quality of life issues were linked to radiographic changes ${ }^{[12]}$. Another study used the SF-36 questionnaire to investigate quality of life among 151 knee OA patients aged 65-75 years in primary care clinics ${ }^{[2]}$. The cross sectional study revealed that $\mathrm{OA}$ patients who attend primary care clinics had poor quality of life due to OA with positive affects on ADL and mental health ${ }^{[2]}$. Another cohort study of 276 patients with severe knee $\mathrm{OA}$ and 228 patients with hip OA used the WOMAC questionnaire to measure pain and stiffness one month after knee and hip replacement procedures ${ }^{[16]}$. The findings indicated that pain and stiffness of the knee and hip were reduced following joint replacement, and that quality of life improved. Another cross-sectional study assessing quality of life in OA patients concluded that better treatment and exercise improve patients' social, physical, and psychological status ${ }^{[7]}$. Araujo et al.'s cross-sectional analysis ${ }^{[8]}$ concluded that functional independence positively affects quality of life. In their comparative cross-sectional study, Murillo et al. investigated how osteoarthritis and comorbidities including diabetes, hypertension, and end-stage renal conditions affected health and concluded that osteoarthritis requires greater consideration ${ }^{[17]}$. Another study confirmed that joint anatomy is disrupted as the disease progresses, and that there is no cure ${ }^{[17]}$. In one randomized control trial ${ }^{[18]}$, patients diagnosed with osteoarthritis and waiting for joint replacement were divided into two groups-one receiving both pharmacological treatment and therapeutic education on functional readaptation (TEFR), and the other receiving only pharmacological treatment. The findings indicated that the negative impact of osteoarthritis was substantially reduced in the former group.
It seems clear from the literature review that $\mathrm{OA}$ of the knee joint impacts significantly on quality of life, and that patients in urban areas and those who understand the disease process exhibit good health-related activity levels. In the present study, the finding that results were the same in two urban areas (one more urbanized) indicates that greater awareness of osteoarthritis is needed in developing countries to improve health-related quality of life.

\section{METHODOLOGY}

\section{Study Design}

Comparative cross-sectional study.

\section{Study Area}

Lahore (population 11,126,285) is Pakistan's second largest city and is more urbanized than Sialkot, the country's thirteenth largest city, which has a population of 655,852 (based on 2017 census figures). The prevalence of OA in urban areas of Pakistan is 28\%; in rural areas, it is $25 \%$. The centers selected for the purposes of this study were the Government Sardar Baigum Hospital, Sialkot; the Government Khawaja Safdar Hospital, Sialkot; the Chauhdry Mohammed Akram Teaching and Research Hospital, Lahore; and the Saeed Orthopedic and Medical Center, Lahore.

\section{Study Duration}

The study was completed during the six-month period from November 2018 to April 2019.

\section{Sample Size}

Of the 158 participating patients, 53 were male and 105 were female.

\section{Sampling Technique}

Data were collected using convenience sampling.

\section{Eligibility Criteria}

\section{a.Inclusion criteria:}

Diagnosis of knee OA (grade 3 or 4 ).

Age 40-80 yrs.

\section{b.Exclusion criteria:}

Any history of systemic disorder (e.g., rheumatoid arthritis, ankylosing spondylitis).

Any history of malignancy.

History of trauma.

Previous knee surgery.

Congenital musculoskeletal deformity (e.g., scoliosis, kyphosis).

\section{Data Collection Tool}

BSF-12 questionnaire. 
Table 1. Socio-demographic profile (qualitative variables).

\begin{tabular}{lccc}
\hline Variable & & Frequency & Percentage \\
\hline \multirow{2}{*}{ Gender } & Male & 53 & 33.5 \\
& Female & 105 & 66.5 \\
\multirow{2}{*}{ City } & Lahore & 79 & 50.0 \\
& Sialkot & 79 & 50.0 \\
\hline
\end{tabular}

Table 2. Socio-demographic profile (quantitative variables).

\begin{tabular}{lcccc}
\hline \multirow{2}{*}{ Age } & Minimum & Maximum & Mean & SD \\
\cline { 2 - 5 } & 41.00 & 80.00 & 48.53 & 10.36 \\
\hline
\end{tabular}

\section{Data Collection Procedure}

Comparative cross-sectional study, using convenience sampling to recruit older patients according to the inclusion criteria of participating Government and private hospitals and clinics in Lahore and Sialkot. The researcher remained anonymous, and all data were collected in a single session. After giving informed consent, patients were asked to complete the SF-12 V2 questionnaire to measure health-related quality of life.

\section{Statistical Procedure}

SPSS 12 was used for data analysis, based on chi square and independent sample t-tests.

\section{Operational Definition}

The 12 items of the SF-12V2 questionnaire address four issues: general health, mental stress, disturbance of ADL, and social activity. (SF-12 v2 is the short form of SF-36.) Individual scoring is based on the following formula:
Transformation of score $=$ actual raw score - lowest possible raw score $\times 100 /$ Possible raw score.

Validity/reliability of SF-12v2 is $0.93-0.96$.

\section{Ethical Issues}

Permission secured from hospital authorities and departments.

Consent form ensuring participants' privacy. Ethical standards maintained throughout.

\section{RESULTS}

Of 158 knee OA patients who participated in the study (53 male and 105 female), participants were drawn equally from Lahore and Sialkot (79 from each city), with a mean age of 48.53 years (Tables 1 and 2).

Tables 3, 4 and 5 summarize responses to the SF-12V2 questionnaire.

Table 6 compares participants' health-related quality of life in the two cities as measured by SF-12. The mean scores were 32.29 \pm 4.97 (Lahore) and 31.89 \pm 4.6 (Sialkot). Based on the independent sample t test, the p-value of 0.57 indicates that there is no significant difference between these two groups in terms of health-related quality of life. According to these results, participants from both cities experienced the same disability level in terms of ADL and exhibited the same level of awareness regarding osteoarthritis. (A p-value of less than 0.05 would be considered significant.)

Table 3. SF-12V2 responses: General health.

\begin{tabular}{|c|c|c|c|c|c|c|}
\hline \multirow{2}{*}{$\begin{array}{l}\text { General } \\
\text { Health }\end{array}$} & \multicolumn{5}{|c|}{ In general, would you say your health is } & \multirow{2}{*}{ p-value } \\
\hline & Excellent & Very good & Good & Fair & Poor & \\
\hline $\begin{array}{l}\text { Lahore } \\
n=79\end{array}$ & $6(7.6 \%)$ & $12(15.2 \%)$ & $26(32.9 \%)$ & $26(32.9 \%)$ & $9(11.4 \%)$ & \\
\hline $\begin{array}{l}\text { Sialkot } \\
n=79\end{array}$ & $3(3.8 \%)$ & $10(12.7 \%)$ & $23(29.1 \%)$ & $28(35.4 \%)$ & $15(19 \%)$ & 0.57 \\
\hline $\begin{array}{l}\text { Total } \\
n=158\end{array}$ & $9(5.7 \%)$ & $22(13.9 \%)$ & $49(31 \%)$ & $54(34.2 \%)$ & $24(15.2 \%)$ & \\
\hline
\end{tabular}

Table 4. SF-12V2 responses: Activities of daily living.

\begin{tabular}{|c|c|c|c|c|}
\hline ADL & Limited a lot & Limited a little & Not limited & p-value \\
\hline \multicolumn{5}{|c|}{ Limitations in moderate activities (e.g., moving a table, pushing a vacuum cleaner, bowling, playing golf) } \\
\hline $\begin{array}{l}\text { Lahore } \\
n=79\end{array}$ & $24(30.4 \%)$ & $43(54.4 \%)$ & $12(15.2 \%)$ & \\
\hline $\begin{array}{l}\text { Sialkot } \\
n=79\end{array}$ & $22(27.8 \%)$ & $49(62 \%)$ & $8(10.1 \%)$ & 0.53 \\
\hline $\begin{array}{l}\text { Total } \\
\mathrm{n}=158\end{array}$ & $46(29.1 \%)$ & $92(58.2 \%)$ & $20(12.7 \%)$ & \\
\hline \multicolumn{5}{|c|}{ Limitations in climbing several flights of stairs } \\
\hline $\begin{array}{l}\text { Lahore } \\
n=79\end{array}$ & $24(30.4 \%)$ & $37(46.8 \%)$ & 18(22.8\%) & \\
\hline $\begin{array}{l}\text { Sialkot } \\
n=79\end{array}$ & $32(40.5 \%)$ & $39(49.4 \%)$ & $8(10.1 \%)$ & 0.58 \\
\hline $\begin{array}{l}\text { Total } \\
\mathrm{n}=158\end{array}$ & $56(35.4 \%)$ & $76(48.1 \%)$ & $26(16.5 \%)$ & \\
\hline
\end{tabular}


Table 5. SF-12V2 responses: Mental stress and social activity.

\begin{tabular}{|c|c|c|c|c|c|c|}
\hline $\begin{array}{l}\text { Mental Stress and } \\
\text { Social Activity } \\
\end{array}$ & All of the time & Most of the time & Some of the time & A little of the time & None of the time & \\
\hline \multicolumn{7}{|c|}{ During the past 4 weeks, have you accomplished less than you would like due to physical health issues? } \\
\hline $\begin{array}{l}\text { Lahore } \\
n=79\end{array}$ & $9(11.4 \%)$ & $32(40.5 \%)$ & $29(36.7 \%)$ & $6(7.6 \%)$ & $3(3.8 \%)$ & \multirow{3}{*}{0.48} \\
\hline $\begin{array}{l}\text { Sialkot } \\
\mathrm{n}=79\end{array}$ & $9(11.4 \%)$ & $30(38 \%)$ & $34(43 \%)$ & $6(7.6 \%)$ & $0(0 \%)$ & \\
\hline $\begin{array}{l}\text { Total } \\
\mathrm{n}=158\end{array}$ & $18(11.4 \%)$ & $62(39.2 \%)$ & $63(39.9 \%)$ & $12(7.6 \%)$ & $3(1.9 \%)$ & \\
\hline \multicolumn{7}{|c|}{ During the past 4 weeks, were you limited in work or other activities due to physical health issues? } \\
\hline $\begin{array}{l}\text { Lahore } \\
n=79\end{array}$ & $10(12.7 \%)$ & $27(34.2 \%)$ & $26(32.9 \%)$ & $11(13.9 \%)$ & $5(6.3 \%)$ & \multirow{3}{*}{0.11} \\
\hline $\begin{array}{l}\text { Sialkot } \\
\mathrm{n}=79\end{array}$ & $5(6.3 \%)$ & $39(49.4 \%)$ & $27(34.2 \%)$ & $7(8.9 \%)$ & $1(1.3 \%)$ & \\
\hline $\begin{array}{l}\text { Total } \\
\mathrm{n}=158\end{array}$ & $15(9.5 \%)$ & $66(41.8 \%)$ & $53(33.5 \%)$ & $18(11.4 \%)$ & $6(3.8 \%)$ & \\
\hline \multicolumn{7}{|c|}{ During the past 4 weeks, have you accomplished less than you would like due to emotional problems? } \\
\hline $\begin{array}{l}\text { Lahore } \\
\mathrm{n}=79\end{array}$ & $12(15.2 \%)$ & $29(36.7 \%)$ & $23(29.1 \%)$ & $14(17.7 \%)$ & $1(1.3 \%)$ & \multirow[b]{3}{*}{0.86} \\
\hline $\begin{array}{l}\text { Sialkot } \\
\mathrm{n}=79\end{array}$ & $9(11.4 \%)$ & $30(38 \%)$ & $28(35.4 \%)$ & $11(13.9 \%)$ & $1(1.3 \%)$ & \\
\hline $\begin{array}{l}\text { Total } \\
\underline{n}=158\end{array}$ & $21(13.3 \%)$ & $59(37.3 \%)$ & $51(32.3 \%)$ & $25(15.8 \%)$ & $2(1.3 \%)$ & \\
\hline \multicolumn{7}{|c|}{ During the past 4 weeks, were you less careful in your work or other activities due to emotional problems? } \\
\hline $\begin{array}{l}\text { Lahore } \\
n=79\end{array}$ & $10(12.7 \%)$ & $25(31.6 \%)$ & $28(35.4 \%)$ & $15(19 \%)$ & $1(1.3 \%)$ & \multirow{3}{*}{0.19} \\
\hline $\begin{array}{l}\text { Sialkot } \\
\mathrm{n}=79\end{array}$ & $8(10.1 \%)$ & $39(49.4 \%)$ & $21(26.6 \%)$ & $9(11.4 \%)$ & $2(2.5 \%)$ & \\
\hline $\begin{array}{l}\text { Total } \\
\mathrm{n}=158\end{array}$ & $18(11.4 \%)$ & $64(40.5 \%)$ & $49(31 \%)$ & $24(15.2 \%)$ & $3(1.9 \%)$ & \\
\hline \multicolumn{7}{|c|}{ During the past 4 weeks, to what extent did pain interfere with your normal work (both work outside the home and housework)? } \\
\hline $\begin{array}{l}\text { Lahore } \\
\mathrm{n}=79\end{array}$ & $5(6.3 \%)$ & $13(16.5 \%)$ & $37(46.8 \%)$ & $10(12.7 \%)$ & $14(17.7 \%)$ & \multirow{3}{*}{0.11} \\
\hline $\begin{array}{l}\text { Sialkot } \\
\mathrm{n}=79\end{array}$ & $7(8.9 \%)$ & $19(24.1 \%)$ & $21(26.6 \%)$ & $17(21.5 \%)$ & $15(19 \%)$ & \\
\hline $\begin{array}{l}\text { Total } \\
\mathrm{n}=158\end{array}$ & $12(7.6 \%)$ & $32(20.3 \%)$ & $58(36.7 \%)$ & $27(17.1 \%)$ & $29(18.4 \%)$ & \\
\hline \multicolumn{7}{|c|}{ During the past 4 weeks, have you felt calm and peaceful? } \\
\hline $\begin{array}{l}\text { Lahore } \\
\mathrm{n}=79\end{array}$ & $6(7.6 \%)$ & $19(24.1 \%)$ & $31(39.2 \%)$ & $21(26.6 \%)$ & $2(2.5 \%)$ & \multirow{3}{*}{0.18} \\
\hline $\begin{array}{l}\text { Sialkot } \\
\mathrm{n}=79\end{array}$ & $2(2.5 \%)$ & $16(20.3 \%)$ & $30(38 \%)$ & $31(39.2 \%)$ & $0(0 \%)$ & \\
\hline $\begin{array}{l}\text { Total } \\
\mathrm{n}=158\end{array}$ & $8(5.1 \%)$ & $35(22.2 \%)$ & $61(38.6 \%)$ & $52(32.9 \%)$ & $2(1.3 \%)$ & \\
\hline \multicolumn{7}{|c|}{ During the past 4 weeks, have you had a lot of energy? } \\
\hline $\begin{array}{l}\text { Lahore } \\
\mathrm{n}=79\end{array}$ & $6(7.6 \%)$ & $17(21.5 \%)$ & $26(32.9 \%)$ & $24(30.4 \%)$ & $6(7.6 \%)$ & \multirow{3}{*}{0.43} \\
\hline $\begin{array}{l}\text { Sialkot } \\
\mathrm{n}=79\end{array}$ & $2(2.5 \%)$ & $14(17.7 \%)$ & $27(34.2 \%)$ & $32(40.5 \%)$ & $4(5.1 \%)$ & \\
\hline $\begin{array}{l}\text { Total } \\
\mathrm{n}=158\end{array}$ & $8(5.1 \%)$ & $31(19.6 \%)$ & $53(33.5 \%)$ & $56(35.4 \%)$ & $10(6.3 \%)$ & \\
\hline \multicolumn{7}{|c|}{ During the past 4 weeks, have you felt downhearted and depressed? } \\
\hline $\begin{array}{l}\text { Lahore } \\
\mathrm{n}=79\end{array}$ & $8(10.1 \%)$ & $22(27.8 \%)$ & $24(30.4 \%)$ & $15(19 \%)$ & $10(12.7 \%)$ & \multirow{3}{*}{0.83} \\
\hline $\begin{array}{l}\text { Sialkot } \\
\mathrm{n}=79\end{array}$ & $11(13.9 \%)$ & $26(32.9 \%)$ & $26(32.9 \%)$ & $15(19 \%)$ & $1(1.3 \%)$ & \\
\hline $\begin{array}{l}\text { Total } \\
\mathrm{n}=158\end{array}$ & $19(12 \%)$ & $48(30.4 \%)$ & $50(31.6 \%)$ & $30(19 \%)$ & $11(7 \%)$ & \\
\hline \multicolumn{7}{|c|}{ During the past 4 weeks, how much of the time has your physical health or emotional problems interfered with your social activities? } \\
\hline $\begin{array}{l}\text { Lahore } \\
\mathrm{n}=79\end{array}$ & $14(17.7 \%)$ & $21(26.6 \%)$ & $29(36.7 \%)$ & $11(13.9 \%)$ & $4(5.1 \%)$ & \multirow{3}{*}{0.83} \\
\hline $\begin{array}{l}\text { Sialkot } \\
\mathrm{n}=79\end{array}$ & $13(16.5 \%)$ & $24(30.4 \%)$ & $26(32.9 \%)$ & $14(17.7 \%)$ & $2(2.5 \%)$ & \\
\hline $\begin{array}{l}\text { Total } \\
\mathrm{n}=158\end{array}$ & $27(17.1 \%)$ & $45(28.5 \%)$ & $55(34.8 \%)$ & $25(15.8 \%)$ & $6(3.8 \%)$ & \\
\hline
\end{tabular}


Table 6. Comparison of health-related quality of life in Lahore and Sialkot.

\begin{tabular}{lcc}
\hline & Lahore & Sialkot \\
\hline $\begin{array}{l}\text { SF-12 Scale } \\
\text { Score }\end{array}$ & $32.29 \pm 4.97$ & $31.89 \pm 4.6$ \\
\hline
\end{tabular}

quality of life among knee OA patients in order to help care providers and physical therapists to understand the impact of the disease. The sample was evenly divided between Lahore and Sialkot; the former is a major urban center while the latter is less urbanized. Although previous studies have found that lifestyle in major urban centers is more sedentary than in smaller cities, there was no significant difference between patients in these two cities in relation to ADL.

The participants included a number of patients with severe $\mathrm{OA}$ who met the criteria for knee replacement. This has been identified as the most effective treatment for knee $\mathrm{OA}$, but the available financial resources are insufficient ${ }^{[19]}$

The present findings align with previous evidence that knee $\mathrm{OA}$ reduces social activity. An earlier study ${ }^{[20]}$ found that $83.5 \%$ of patients indicated severe or some limitation when climbing stairs and during housework. In another study, $76 \%$ of OA patients felt depressed most or some of the time while $26 \%$ felt little or no depression. These results align with other evidence of high levels of depression among knee OA patients ${ }^{[20-22]}$.

Osteoarthritis is a degenerative disease that affects older populations everywhere. The present findings indicate that knee OA patients experience the greatest limitations in ADL, especially in relation to stair climbing and moderate activities such as cleaning the house. The study also confirms that a significant number of patients who experience these limitations also suffer from depression. These patients should be provided with the necessary resources to identify and address their concerns, including support groups and rehabilitative physical therapy, as their anxiety and pain can lead to depression ${ }^{[23]}$.

Orthopedic surgeons and physiotherapists can help to improve ADL among knee OA patients. Pain and swelling can be managed through lifestyle modification, medication, and physical therapy, all of which can reduce the impact of disease and so improve quality of life and social behavior.

\section{STUDY LIMITATIONS}

The study period was relatively short. Patients were reluctant to provide data.

The male-female ratio was not balanced.

\section{CONCLUSION}


from a population survey in Norway. The Journal of rheumatology, 35(4), 677-684.

6. Felson, D. T., Naimark, A., Anderson, J., Kazis, L., Castelli, W., \& Meenan, R. F. (1987). The prevalence of knee osteoarhritis in the elderly. The Framingham Osteoarthritis Study. Arthritis \& Rheumatism: Official Journal of the American College of Rheumatology, 30(8), 914-918.

7. Jack Farr, I. I., Miller, L. E., \& Block, J. E. (2013). Quality of life in patients with knee osteoarthritis: a commentary on nonsurgical and surgical treatments. The open orthopaedics journal, 7, 619.

8. Araujo, I. L. A., Castro, M. C., Daltro, C., \& Matos, M. A. (2016). Quality of life and functional independence in patients with osteoarthritis of the knee. Knee surgery \& related research, 28(3), 219.

9. Roos, E. M. (2005). Joint injury causes knee osteoarthritis in young adults. Current opinion in rheumatology, 17(2), 195-200.

10. Andriacchi, T. P., \& Mündermann, A. (2006). The role of ambulatory mechanics in the initiation and progression of knee osteoarthritis. Current opinion in rheumatology, 18(5), 514-518.

11. Anderson, J. J., \& Felson, D. T. (1988). Factors associated with osteoarthritis of the knee in the first national Health and Nutrition Examination Survey (HANES I) evidence for an association with overweight, race, and physical demands of work. American journal of epidemiology, 128(1), 179-189.

12. Salaffi, F., Carotti, M., \& Grassi, W. (2005). Health-related quality of life in patients with hip or knee osteoarthritis: comparison of generic and disease-specific instruments. Clinical rheumatology, 24(1), 29-37.

13. De Jong, O. R. W., Hopman-Rock, M., Tak, E. C. M. P., \& Klazinga, N. S. (2004). An implementation study of two evidence-based exercise and health education programmes for older adults with osteoarthritis of the knee and hip. Health education research, 19(3), 316-325.

14. Brosseau, L., Wells, G. A., Kenny, G. P., Reid, R., Maetzel, A., Tugwell, P., ... \& Chen, L. (2012). The implementation of a community-based aerobic walking program for mild to moderate knee osteoarthritis (OA): a knowledge translation (KT) randomized controlled trial (RCT): Part I: The Uptake of the Ottawa Panel clinical practice guidelines (CPGs). BMC public health, 12(1), 871.
15. Kanavaki, A. M., Rushton, A., Efstathiou, N., Alrushud, A., Klocke, R., Abhishek, A., \& Duda, J. L. (2017). Barriers and facilitators of physical activity in knee and hip osteoarthritis: a systematic review of qualitative evidence. BMJ open, 7(12), e017042.

16. Jones, C. A., Voaklander, D. C., Johnston, D. W., \& Suarez-Almazor, M. E. (2000). Health related quality of life outcomes after total hip and knee arthroplasties in a community based population. The Journal of rheumatology, 27(7), 1745-1752.

17. Murillo, Y. A., Almagro, R. M., Campos-González, I. D., \& Cardiel, M. H. (2015). Health related quality of life in rheumatoid arthritis, osteoarthritis, diabetes mellitus, end stage renal disease and geriatric subjects. Experience from a General Hospital in Mexico. Reumatología Clínica (English Edition), 11(2), 68-72.

18. Nunez, M., Nunez, E., Segur, J. M., Maculé, F., Sanchez, A., Hernández, M. V., \& Vilalta, C. (2007). Health-related quality of life and costs in patients with osteoarthritis on waiting list for total knee replacement. Osteoarthritis and cartilage, 15(3), 258-265.

19. Fransen, M., Bridgett, L., March, L., Hoy, D., Penserga, E., \& Brooks, P. (2011). The epidemiology of osteoarthritis in Asia. International journal of rheumatic diseases, 14(2), 113-121.

20. Vaughan, M. W., Felson, D. T., LaValley, M. P., Orsmond, G. I., Niu, J., Lewis, C. E., ... \& Keysor, J. J. (2017). Perceived Community Environmental Factors and Risk of Five-Year Participation Restriction Among Older Adults With or at Risk of Knee Osteoarthritis. Arthritis care \& research, 69(7), 952-958.

21. Fukutani, N., Iijima, H., Aoyama, T., Yamamoto, Y., Hiraoka, M., Miyanobu, K., ... \& Matsuda, S. (2016). Knee pain during activities of daily living and its relationship with physical activity in patients with early and severe knee osteoarthritis. Clinical rheumatology, 35(9), 2307-2316.

22. Sherman, A. M. (2003). Social relations and depressive symptoms in older adults with knee osteoarthritis. Social science \& medicine, 56(2), 247-257.

23. Abbasnia, V. S. (2016). The effect of Citrus Aurantium flowers aqueous extract on sleeping time and the level of anxiety in mice. Journal of Birjand University of Medical Sciences, 23(4), 307-314. 